University of Michigan Law School

University of Michigan Law School Scholarship Repository

Articles

Faculty Scholarship

1920

\title{
Epithetical Jurisprudence and the Annexation of Fixtures
}

Joseph H. Drake

University of Michigan Law School

Available at: https://repository.law.umich.edu/articles/1249

Follow this and additional works at: https://repository.law.umich.edu/articles

Part of the Common Law Commons, and the Property Law and Real Estate Commons

\section{Recommended Citation}

Drake, Joseph H. "Epithetical Jurisprudence and the Annexation of Fixtures." Mich. L. Rev. 18 (1920): 405-9.

This Response or Comment is brought to you for free and open access by the Faculty Scholarship at University of Michigan Law School Scholarship Repository. It has been accepted for inclusion in Articles by an authorized administrator of University of Michigan Law School Scholarship Repository. For more information, please contact mlaw.repository@umich.edu. 


\section{Michigan LAW RevieW}

\section{PUBLISHED MONTHLY DURING THE ACADEMIC YEAR, EXCLUSIVX OP OCTOBER, DY THX \\ LAW SCHOOL OF THE UNIVERSTY OF MICHICAR}

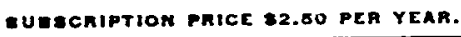

so cente per numgen

Ralph W. Aigler, Ediror-in-Chief

ASSOCIATE EDITORS

HENRY M. Bates

E. C. Godpard

EDSON R. SUNDERLAND

Joseph H. Drake

JoHN B. WAITE

STUDENTS, APPOINTED BY THE FACULTY

ALsN W. Boyd, of Indiana

Bes B. Afatrhews, of Arkansas

Morse D. Caypaele, of Michigan

Frayk C. Patterson, of Michigan

Rolia L. Carpenter, of Michigan

Lisle L. Pollcck, of Michigan

RoBert G. DAy, of Obio

Jesse M. Seabright, of Ohio

HEN RY I. EAGER, of Kentucky

Harold M. Shapero, of Michigan

Lours Kuwis, of Michigan

George $H$. Kretzsch Mar, of Michigan

Harold R. SMItr, of Michigan

LEwis H. Matters, of Ohio

Winter N. SNow, of Maine

ARVID B. TANNER, of Minnesota

Lester E. Watergury, of Illinois

\section{NOTE AND COMMENT}

Eptrhetical Jurisprudence, and The Annexatyon of Fixtures.-If we begin with all the facts of a controversy and proceed inductively to determine the rights of the parties litigant, we thus arrive at a jurisprudence of rights, whereas, if we reason deductively from a rule, a definition, or a maxim of law to its application in the facts of our case, we can at best attain only a jurisprudence of rules, which has been so aptly characterized as an epithetical jurisprudence. The subject of fixtures is one in which we have great difficulty in spplying the inductive method because the courts have been slower in approaching the subject scientifically in this field of the law than in others.

In the recent case of Hanson v. Voss, (Minn., Dec. 12, 1919), $175 \mathrm{~N}$. W. II3, the court decides that "if the holder of a ground lease erects an apartment building and installs a gas range and a door-bed in each flat and thereafter forfeits the lease, these articles will pass as fixtures to the owner of the realty, if no rights of a third party are infringed and there is no agreement to the contrary." The law of the case is well stated in the syllabus, and is in accord with the weight of authority, and the opinion has the least possible 
discussion of definition of fixtures and of annexation. It would seem that this court has donc its best to escape from the older mechanical seasoning and comes out right because it does not proceed deductively from a definition to its appliration in the particular instance, but by the inductive approach to the rights of the parties on the basis of all the facts. The court says, "the manner of annexation is not decisive but only one of the several facts to be taken into account." This is in refreshing contrast to the earlier cases with their labored grammatical interpretations of the word "annexation." The historical route over which the courts have traveled to reach this rational law is perhaps worth retracing.

In an Anonymous Case, Y. B., 21 Hen. VII, 26, pl. 4, (1506), a furnace fixed to the freehold descended to the heir. In Herlakenden's Case, 4 Co. 6za, $63 \mathrm{~b}$, (1589), wainscoting nailed to the wall went to the heir. In this case the court said, "be it annexed to the house by the lessor or lessee it is parcel of the house." In Squier v. Mayer, Freem. C.C. 249, (I70I), it was decided that a furnace fixed to the freehold and hangings nailed to the wall went to the executor. The reason for these contradictory decisions is easy to see. During the sixteenth and seventeenth centuries, in all questions of property law, the concept of seisin is uppermost in the minds of the courts. Now it is evident that if there is affixing of the material of the chattel to the realty, either by accession or by annexation, the holder of the realty is seised of the fixture. As the mind of the court is thus fixed on the annexation, the intention of the party who annexes is ignored. Indeed, in the dictum in Herlakenden's Case, supra, the court said that the intention of the lessor or lessee had nothing to do with the decision. It is a matter of some surprise that the courts did not avail themselves of the precedent in Roman law in regard to "immovables by destination," which had existed since the time of Labeo (see citation given later). Bracton apparently followed the classic Roman law in this. He says horreum frumentarium novum, *** in praedio Semphronii positum, non erit Semphronii (lib. 2, c. 2, Section 4, fol. io). Bracton is here talking of accession and not of annexation, to be sure, but the crib destined for storing grain is described as movable because of this destination and not as an immovable, although it is firmly affixed to the soil of Sempronius. The courts of this period were certainly well versed in the Roman law, as we know from Lord Holt's celcbrated excursus on bailments in the case of Coggs v. Bernard, 2 Ld. Raymond, 909 (170r). Sir Nathan Wright, who presided over the chancery court and gave the opinion in Squier r. Mayer, was a contemporary of Lord Holt, but the Lord Kecper is apparently blinded here by the concept of seisin, so that he fails to see the possibility of help from the Roman source. The common law concept of seisin seems to have the same effect on him that it had on Lord Holt in Heydon v. Heydon, I Salk. 392, (1693), where Holt decides that partners are seised as joint tenants, and ignores the holding as tenants in partnership, iust as here the Lord Keeper sees the annexation but misses the evidences of intent. The only reason that the court in Squicr v. Mayer reaches a conclusion contrary to that of the Anonymous Case of 1506 (supra), and of Herlakenden's Case (supra) is that it interprets the facts differently. There 
is no hint that the court considers at all the intention of the parties. It is possible that we have here a premonition of the decision in Wiltshear v. Cottrell (post) in which attachment by gravity alone is held not to be annexation. It will be observed, too, that as half these cases were decided one way and half the other, on the same state of facts, the deductive procedure by the definitional route has brought us to the right conclusion in only fifty per cent of the cases.

During the eighteenth century the courts that followed these cases as precedents would come out on one side or the other according to whether the physical nexus were more or less intimate. This practically reduced the law on the subject to a nullity as the only question was one of physical fact. Even Lord Mansfield who begins to swing toward the test of intention as being the more significant, speaks of the "reason of the things," first, and the "intention," second; and by the "reason of the thing" he apparently means that they have become annexed to the inheritance. He calls them "accessories." Lawton v. Salmon, 2 H. B1. 259 note (K. B. 1782).

As late as the latter half of the nineteenth century the English court decided that a heavy building, attached to the earth only by its weight. was, as a matter of definition, not legally annexed. The court said, "we are bound by the authorities to consider such an erection as a mere chattel." Wittshear v. Cottrell, I E. \& B., 2 Q. B. 674, (1853). This seems to establish, or confirm, the doctrine that attachment by gravity alone is not annexation. In the next year, however, the New York Court in Snedeker v. Waring, Io N. Y. 170, I75, (1854), said, "a thing may be as firmly fixed to the land by gravitation as by clamps or cement." Thus far, the New York Court follows the English case in its grammatical method of interpretation of the word "annexation," but comes to a diametrically opposite conclusion, i. c., that a material nexus, is not necessary, if we have the invisible, intangible, force of gravitation to hold the chattel to the realty. Dean Pound has called attention to the fact that in the period succeeding our American Revolution the Anglophobia of the times sometimes got into our courts. Either because of his prejudice or because the court recognized that the Roman law would strengthen the decision, which was in direct conflict with that of the English Court in Wiltshear v. Cottrell, he quoted the rule from Labeo that the court had missed in the case of Squier v. Mayer, supra. Ulpian says that, Labso generaliter scribit ea, quae perpetui usus causa in aedificiis sunt, aedificii esse. Dig. 19, 1, 17. This is the basis of the rule in modern French law relative to immovables by "destination." Cf. Code Napoleon, Section 524; also Bracton l. c. supra. Cf. also La. Civ. Code, Section 468.

It may be remarked in passing that, although the word "destination" of the French Code seems to cover the same ground as "intention" in English law, there are some important distinctions between them Fixtures in Englisk. law can include only inanimate objects, while pigeons in their cotes, rabbits in their warrens, fish in fish ponds, may be immeuble par destination. Also in French law no one can make a fixture except the owner. See Code Napoleon, annotated by Blackwood Wright, Section 524, note (a). 
This quotation fron laluco carries us back to the Golden Age of Roman law. Ulpian was one of that great coterje of philosophic jurists of the third century of the Christian erit, and Labeo, whom he quotes, belonging to the Age of Augustus, was one "in whom a wider culture had instilled a love of Seneral principles." The New York Court, in Snedeker v. Waring, by adopting the Roman law principle into our system, has brought our law into conformity with justice. By comparing the English case of Wiltshcar v. Cottrell and the American case of Sincdeker v. Waring, both belonging to the middle of the nineteenth century, with the cases of the sixteenth and seventeenth centuries, quoted above, it will be noted that the late cases come out just as the earlier ones, half right and half wrong, on exactly the same state of facts, so long as we reason deductively from the definition of "annexation," giving to the word in the one case the strictly literal meaning of annexation; $i$. e., a physical interlocking of the particles of matter, and in the other, the holding together by an intangible force. But just as soon as the court realizes that the real question to be decided is not the grammatical meaning of a word but what should be the rights of the parties under all the facts in the controversy, we arrive at conclusions in accordance with justice and fair dealing. The facts to be considered are in general:

(I). The physical relations of the things, i. e., the nature of the annexation (see all the old cases cited above).

(2). The intention of the parties; to be determined, (a) by the relations of the parties, whether landlord and tenant (the ordinary case); mortgagor and mortgagee, Holland v. Hodgdon, Exch. Ch. L. R. 7 C. P. 328 (1872); vendor and vendee, Dustin v. Crosby, 75 Me. 75 , ( 1883 ); simple tort feasor or one acting with the purpose of condemning the property, Justice $v$. Nesquehoning Valley Ry. Co., $87 \mathrm{~Pa} .28$ (I878). (b) by the nature of the thing, i. e., whether trade fixture or not, Squire \& Co. v. Portland, $106 \mathrm{Me}$. 234, (1909). (c) by the custom of the locality. Gas stoves, realty, Bank v. Realty, Corp., 137 App. Div. (N.Y.) 45, (I910); also the principal case. Gas stoves, personalty, Hook v. Bolton, 199 Mass. 244, (1908). The New York Court in deciding Bank v. Realty Corp. said, "It is a matter of common knowledge [in King's County] that heating and cooking form a part of the recessary and permanent equipment of a tenement house; that they are not ordinarily supplied by tenants, and there is evidence in the record of such custom." Following a similar course of reasoning, the Massachusetts court in Hook v. Bolton, supra, quotes from a previous Massachusetts' decision to the effect that "the tendency of the modern cases is to make this a question of the intention with which the machine was put in place. Hopewell Mills v. Taunton Sazings Bank, 150 Mass. 522 (1890).

If the courts would only pay due heed to this suggestion of the Massachusetts court and forget the age-long grammatical litigation of the word "annexation," it would go far toward attaining just decisions in the majority of cases, and would free our reports of much useless lumber in the citation of ancient precedents. In every instance the question is not what the name of a legal concept is, but what can the partics legally do. What the courts have Jone is certainly law, and is more significant than what the courts have 
said about the nature ot a legal concept. By sceking first a definition and then proceeding by the formal grammatical method of the sixteenth century, we reach the goal of justice in about half the cases. If we ask first, what the rights of the litigant parties are, and then inquire, what are the facts of the controversy; including, first, the physical relations of the things, then, the character of the parties, the nature of the thing, and the custom of the locality, in order to satisfy the reasonable expectation and legal intention of the parties to the controversy, we increase the coincidence of law and justice by nearly a hundred per cent. In the interest of the efficient administration of justice, the modern scientific method seems to have decided advantages.

J. H. D. 